\title{
مصطلح "الضرورة الشعرية"
}

\section{د. عبد الحميد عثمان زرموح}

كلية الآداب - جامعة مصراتة

\section{تقديم:}

الشعر والنحو متلازمان في حياة العرب منذ القِدَم، أما الشعر فلأنه وليد الشعور، وهو

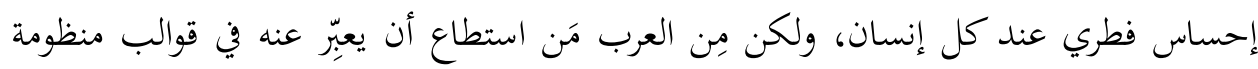
ذات نغمات خاصة عُرفتْ فيما بعد بالأوزان، والتزموا في كل قطعة منها فهاية واحدة هي القافية، وهكذا فالشعر كلام موزون مقفَّى، يحمل الأحاسيس والصور والمعاني المتعددة.

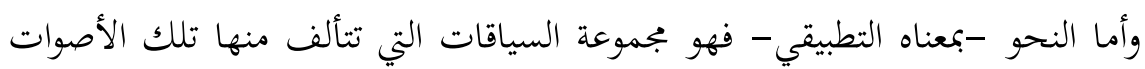

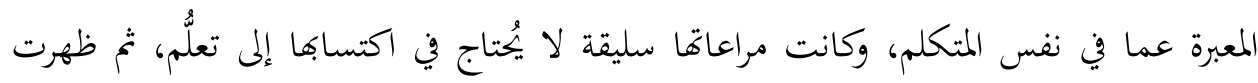
الحاجة إلى وضع ضوابط لتقيَها التغير والضياع، في صورة أحكام عامة في اللغة والنحو - كما هو معلوم من تاريخ نشأة علوم اللغة بعامة، وعلم النحو بخاصة-.

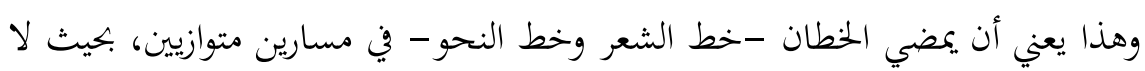

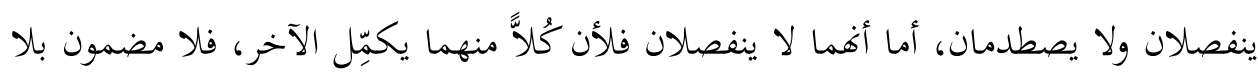
صورة ولا صورة بلا مضمون، وأما أفما لا يصطدمان فلأن الخطين المتوازيين لا يلتقيان مهما

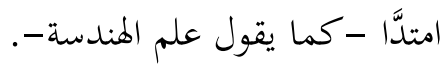
هذا هو الأصل في العلاقة بين اللفظ والمعنى في العربية، وهذا التعبير لا يخلو: إما أنه

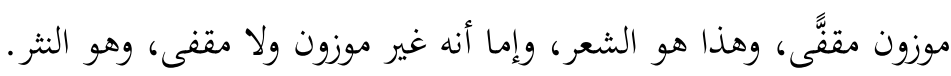

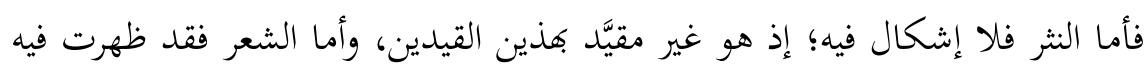
حالات لمُ يُراعَ فيها هذا الأصل، حيث خرج بعض الشعراء عن تلك الأحكام اللغوية والنحوية

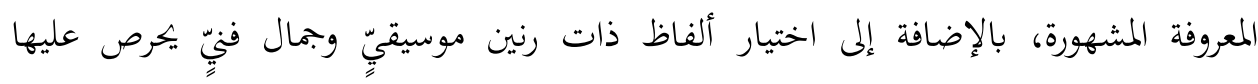


الشاعر؛ لأنه يراها مهمة جلَّا في عمله؛ ومن هنا نشأ هذا الإشكال في الشعر دون النثر، وهو ما بات يُعرَف باسم "الضرورة الشعرية". من المفيد أولاً تقرير أن العلماء قد أجمعوا على التسامح في ذلك -إجمالاً-، وقبوله بوصفه وضعاً خاصاً من الكلام، ثم اختلفت كلمتهم في تفسير ذلك الوضع وتحديد مداه، فذهبوا فريقين: أحدهما قَبَلَهُ غيرَ مشروطِ، والآخر قَبَلَهُ مشروطاً.

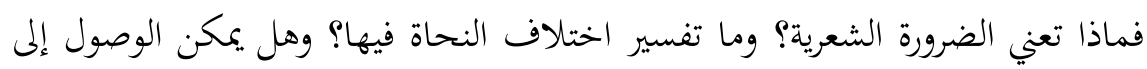
موقف منها يُرضِي الجميع؟ هذا ما تحاول الصفحات الآتية مناقشته، والإجابة عنه.

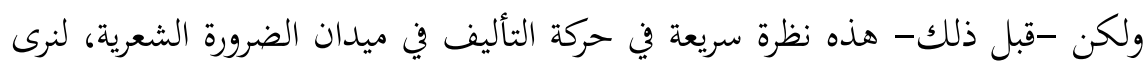

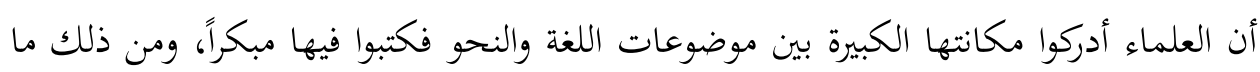
نجده من إشارات إليها في كتبهم، ومنهم:

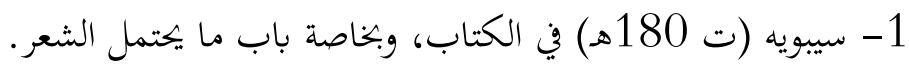
2- ابن السرَّاج (ت 316هـ) في الأصول في النحو.

3- الرماني (ت 384 هـ) في شرحه على الكتاب، في باب الترخيم في ضرورة الشعر. 4- ابن رشيق (ت 463 هـ) في العمدة. 5- البطَلُْوسي (ت بعد 630هـ) في شرح كتاب سيبويه. 6- ابن عصفور (ت 669هـ) في شرح الجمل والمقرِبِ. 7- حازم القرطاجني (ت 684 هـ) في مناهج البلغاء. 8- أبو حيان (ت 745هـ) في ارتشاف الضرَب. 9- السبكي (ت 763 هـ) في عروس الأفراح. 10. الشاطبي (ت 790 هـ) في شرحه على الألفية. تم صُنِفت فيها الكتب المتخصصة، ومنها: 1- ضرورة الشعر، للمبرد (ت 286هـ).

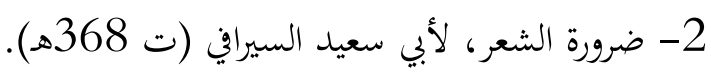




$$
\begin{aligned}
& \text { 3- ضرورة الشاعر، لابن جني (ت 392هـ). } \\
& \text { 4- ذنُّ الخطأِ في الشعر، لابن فارس (ت 395هـ). } \\
& \text { 5- ضرائر الشعر، للقيرواني (ت 412هـ). } \\
& \text { 6- ضرائر الشعر، لابن عصفور (ت 663هـ). }
\end{aligned}
$$

7- منظومة كفاية الغلام في إعراب الكلام، للآثاري (ت 828هـ).

$$
\text { 8- الضرائر، للألوسي (ت 1342هـ) (1). }
$$

1- الضرورة الشعرية، "دراسة نقدية لغوية"، للدكتور عبد الوهاب العدواني.

2- الضرورة الشعرية في النحو العربي، للدكتور مُعَّمَ حماسة عبد اللطيف.

$$
\text { 3- في الضرورة الشعرية، للدكتور خليل بنيان الحسون. }
$$

4- الضرورة الشعرية، "دراسة أسلوبية"، للدكتور السيد إبراهيم عُمَّه.

5- سيبويه والضرورة الشعرية، للدكتور إبراهيم حسن.

\section{المطلب الأول: "الضرورة" في اللغة}

لم تختلف معاجم اللغة وكُتب التعريفات كثيراً في التعبير عن ماهية الضرورة في اللغة، أي في الاستعمال العربي قبل ظهور العلماء والباحثين عن معناها الاصطلاحي في الشعر بخاصة، ففي لسان العرب: (( وقد اضطُرّ إلى الشيء أي أُلجئ إليه ... الضرورة: اسم لمصدر الاضطرار، تقول: حملتني الضرورة على كذا وكذا، وقد اضطر فلان إلى كذا وكذا. بناؤه (افتعلَ) فجُعِلت التاءُ طاءٌ؛ لأن التاء لم يحسن لفظه مع الضاد )(2).

1- ينظر في هذه المؤلَّفات: الفهرست، معجم المؤلفين، كشف الظنون.

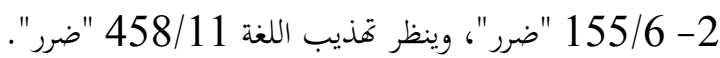


فهذا يعني أها من الاضطرار، وفِعله (اضترَّ) بزنة (افتعل)، ولكن لَمَّا لمُ يسهل نُطْق التاء

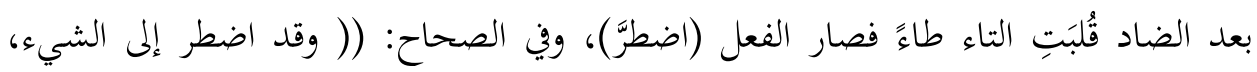

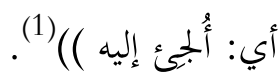

وجاء في التعريفات: (( الضرورة مشتقة من الضرر، وهو النازل مما لا مدفع له ))(2). وهي في المعجم الوسيط: (( الحالة الداعية إلى أن يُرتخَب فيه -أي الشعر - ما لا يُرتكَب في

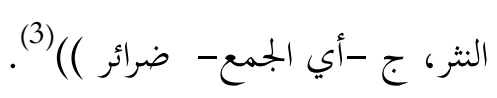

وفي التاج: (( والاضطرار: الاحتياج إلى الشيء، وقد اضطره إليه أمرٌ: أحوجه وألجأه، فاضطر بضم الطاء ... والضرورة: الحاجة، ويُجمع على الضرورات كالضارورة والضارور والضاروراء () (4)

وفي كتاب الجمهرة: (( والضرورة والضارورة واحد، وهو الاضطرار إلى الشيء ))(5).

$$
\text { وفي معجم متن اللغة: (( الضرورة: الحاجة، ج: ضَرورات )) (6). }
$$

وفي الهادي إلى لغة العرب: (( هي الحاجة الْمُلجِئة، والجمع ضرورات )) (7).

وفي محيط المحيط: (( واضطُرّة إليه اضطراراً: احتاج إليه، واضطره إليه: أحوجه وألجأه،

فاضطرُ هو -بصيغة المجهول- أي ألجلجئ ()(8).

$$
\begin{array}{r}
.720 / 2-1 \\
.143 \text { " } 72-2 \\
.540 / 1-3 \\
.349 / 3-4 \\
.122 / 1-5 \\
.544 / 3-6 \\
.79 / 3-7 \\
.533 \text { ص - } 8
\end{array}
$$


وفي الكافي: (( الضرورة الحاجة ... أي: أن الحاجة تدفع بصاحبها إلى عمل ما هو

منمنوع (1)

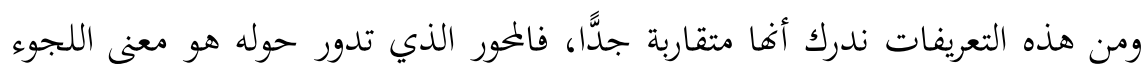

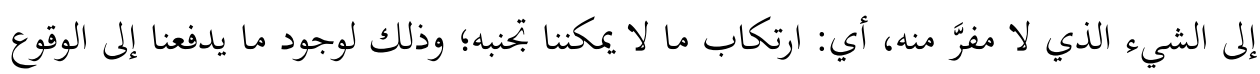

المطلب الثاني: بين مصطلح الضرورة ومصطلَحَي الاطِّراد والشذوذ

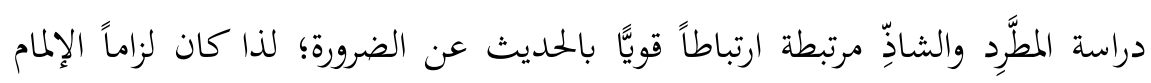

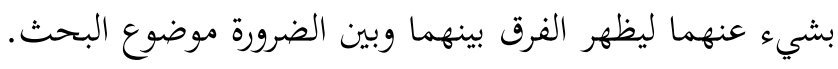

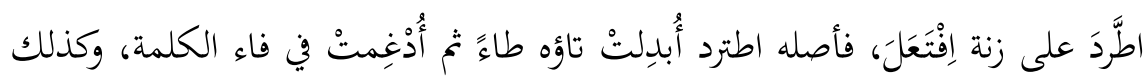

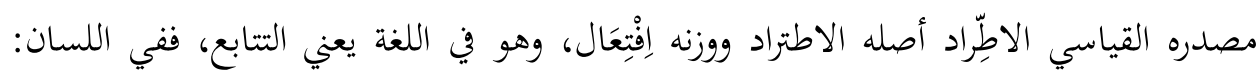

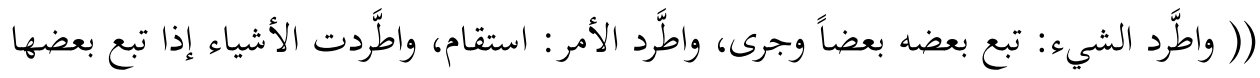

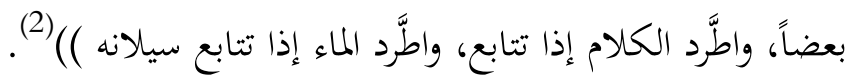

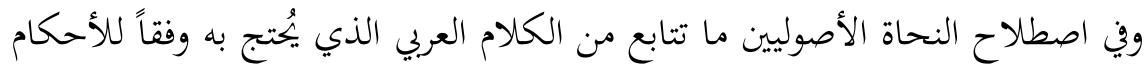

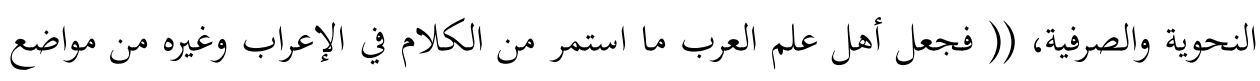

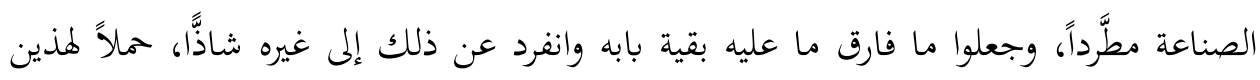

الموضعين على أحكام غيرهما ()(3)

فالشاذُّ في اللغة هو المنفرد عن غيره، جاء في الصحاح: (( شذَّ عنه يشُّن ويشِذ شُذوذاً:

$$
\text { انفرد عن الجمهور، فهو شاذّ )(4). }
$$

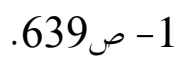

$$
\begin{aligned}
& \text { 2-268/3 "طرد"، وينظر الصحاح 502/2 "طرد". }
\end{aligned}
$$

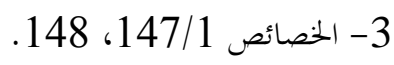

$$
\begin{aligned}
& \text { 4- 565/2 "شذذ"، وينظر اللسان 494/3 "شذذ". }
\end{aligned}
$$


وفي الاصطلاح: ما خالف القياس، قال البغدادي (ت 1093ه): (( والشاذ: هو

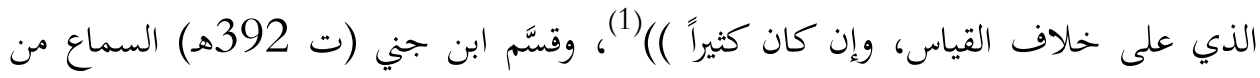
حيث الاطراد والشذوذ إلى أربعة أقسام:

الأول: ما اطَّدد في الاستعمال والقياس معاً، وهذا هو غوراد غالب أساليب العربية وقواعد النحو، كرفع الفاعل، ونصب المفعول، وجرٍّ الاسم إذا دخلتْ عليه حروف الجر، ونحو ذلك، وهذا حُجة بالإجماع؛ لأنه الغاية المطلوبة. الثاني: ما اطرد في القياس دون الاستعمال، كالماضي من يذر ويدع، ووجه اطراد هذين المثالين في السماع دون القياس: أن المعروف قياساً في أساليب العرب أن يكون لكل فعل مضارع فعل ماضٍ، بيد أن العرب لمج يستعملوا هذا القياس في بعض أفعال المضارع، نهو يذر

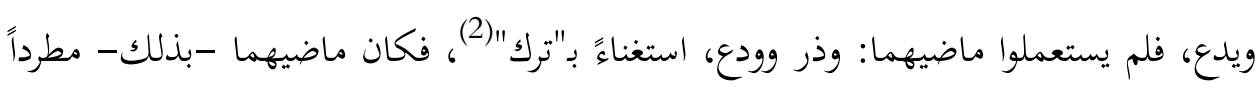
في القياس على بابه، شاذًا أي: قليلاً في استعمال العرب(3). ومن أمثلة ذلك -أيضاً-: (( مكان مُبْبِل ))(4)، هذا هو القياس؛ لكن العرب أكثروا استعمال باقِل، فالأول مسموع على القلة(5)، ومنه كذلك استعمال الاسم الصريح مفعولاً لـ"عسى"، نحو قولم: عسى زيلٌ قائماً أو قياماً، فهذا هو القياس، غير أن السماع ورد بجظره، والاقتصار على تروك استعمال الاسم هنا، فيقولون: عسى زيدٌ أن يقوم (6) ومنه قوله -تعالى-:

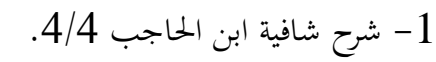
2- 2 ينظر الأصول لابن السراج

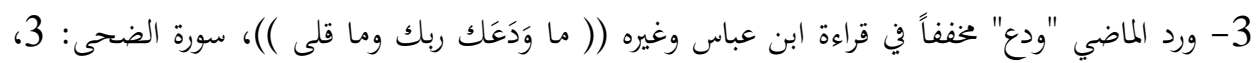

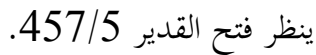
4- 148/1 الخصائص

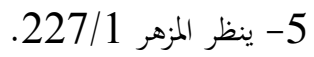

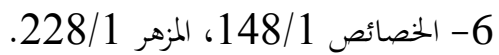




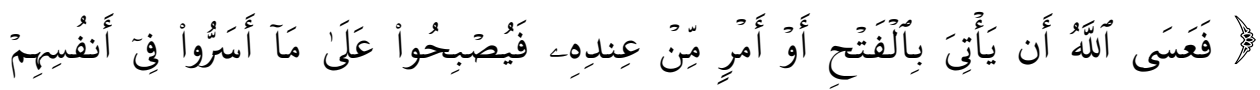

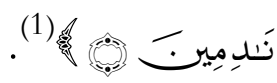

تمث بيَّن ابن جني أن الواجب في هذا النوع هو الاقتداء بالعرب، وترّكُ ما تركوه من ذلك،

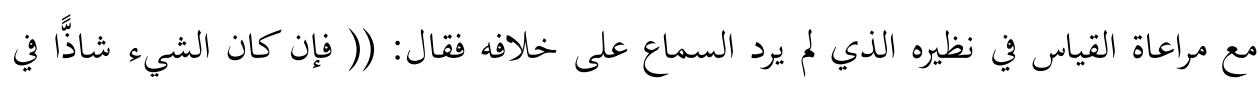

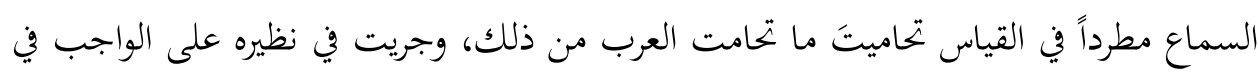

أمثاله () (2)

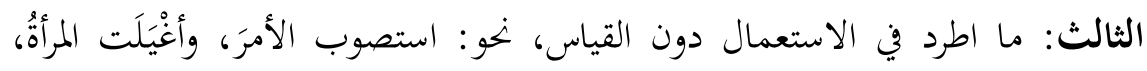

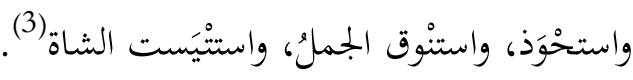

ووجه شذوذ هذه الأمثلة عن القياس: هو أن القياس الجاري في كلام العرب أنه إذا

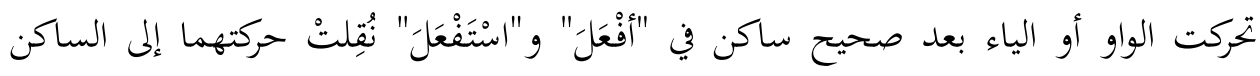

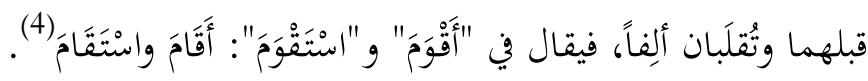

وعن حكمه قال ابن جني (ت392هـ): (( واعلم أن الشيء إذا اطرد في الاستعمال

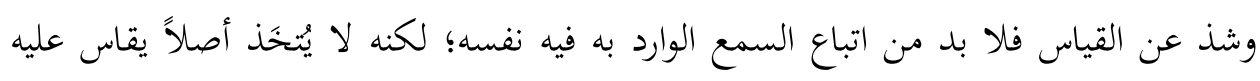

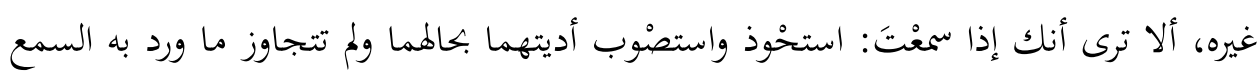

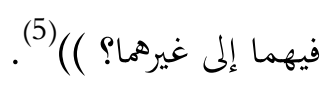

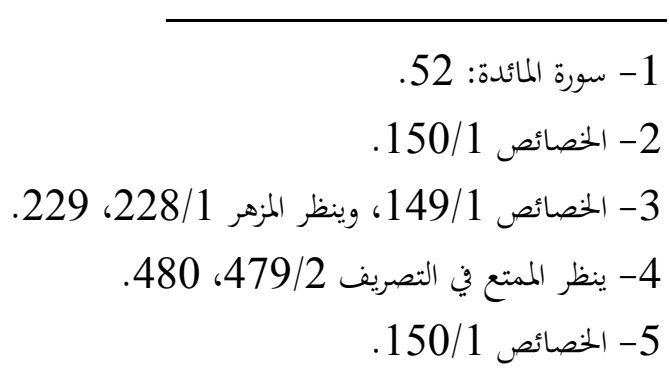


الرابع: ما شذ في الاستعمال والقياس معاً، ونجده في صياغة اسم المفعول منا اعتلت

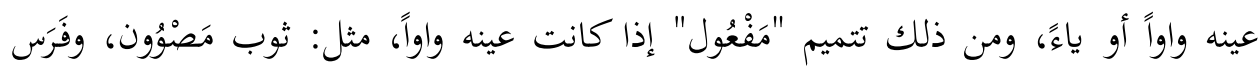
مَحقُوْود، ورَجُل مَعْوُود، فهذه الأمثلة وما ضارعها كلها شاذة قياساً واستعمالاً.

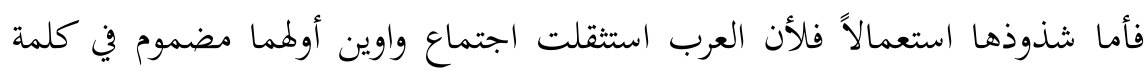
واحدة)

وأما شذوذها قياساً فقد أوضحه ابن عصفور (ت663هـ) بأن القياس يقضي بمجيئه

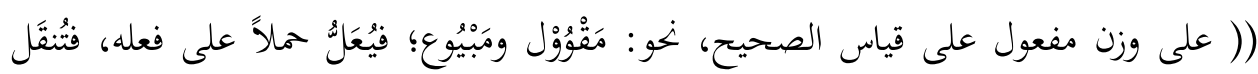

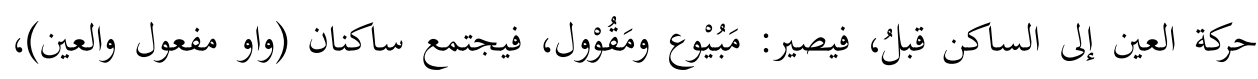

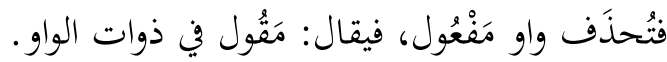

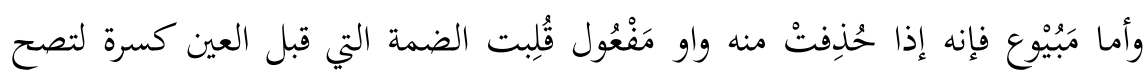
الياء، فتقول: مَبِيع () (2).

المطلب الثالث: "الضرورة الشعرية" عند النحاة

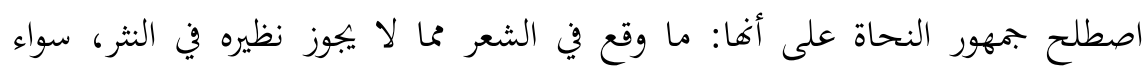
أكان للشاعر عنه مندوحة أم لا(3). والمندوحة هي السَّعة والْمَخرَج، ففي اللسان: (( والمندوحة هي السَّعة والفسحة، وقالوا:

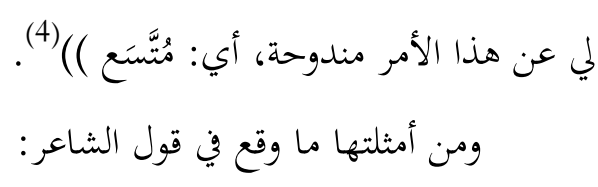

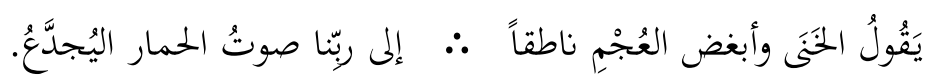

1- 1- ينظر الكتاب 348/4، الممتع ص454،

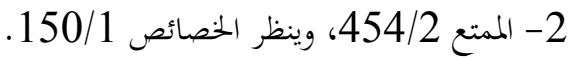

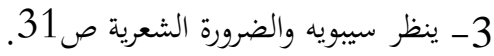

$$
\begin{aligned}
& \text { 4- لسان العرب 161/6 "ندح". }
\end{aligned}
$$


(( فيه ضرورة عند الجمهور، وهي إدخال "أل" الموصولة على صريح الفعل المضارع

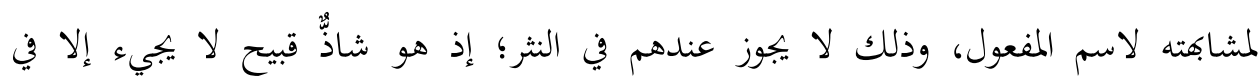

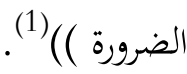

أي: أن الوزن الشعري قيَّد الشاعر وجعله يُدخِل "أل" على الفعل المضارع "يُجدَّع"، ولا يستقيم الوزن من دوغها، فاضطر إلى ارتكاب هذه المخالفة حِفاظاً على استقامة الوزن. ومثل الشعر في هذا الحكم فواصلُ القرآن الكريم والكلامُ المسجوع؛ فمن الفو الفواصل

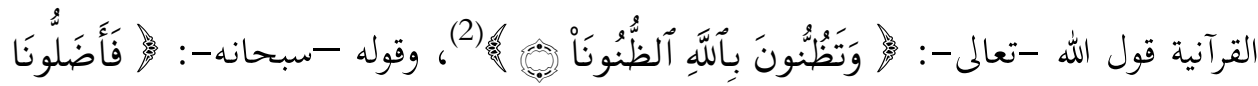

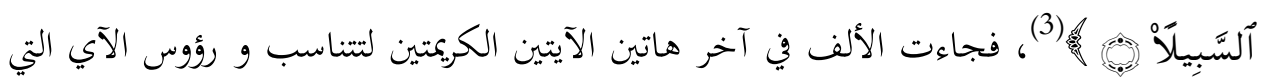
قبلها وبعدها.

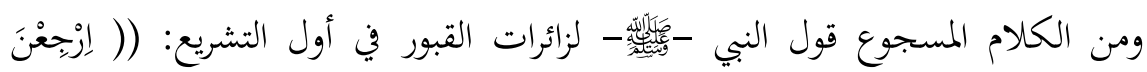

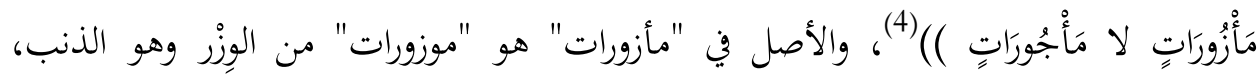

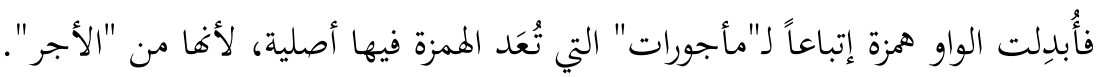
أما في غير هذين الضربين فلا يُسمح بارتكاب المخالفات النحوية -بخاصة- واللغوية

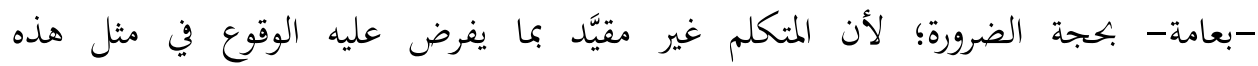
المخالفات (5)

فجمهور النحاة وغالبيتهم يذهبون إلى أن الضرورة ما وقع في الشعر مطلقاً، أي: سواء

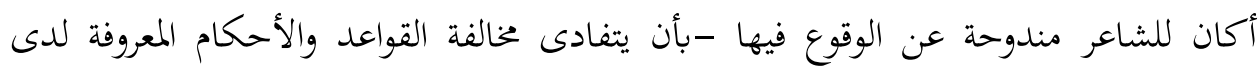

1- سيبويه والضرورة الشعرية ص313، والبيت لذي الخرق الطهوي، ينظر الإنصاف 151/1.

$$
\text { 3- 1- سورة الأحزاب: } 10 .
$$

4- سنن ابن ماجة (باب ما جاء في اتباع النساء الجنائز) 502/1، 503، 503، (رقم 1578).

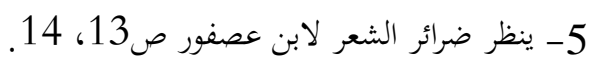


الجميع-، أم لم يكن في مقدوره إلا الوقوع فيها؛ ولتفصيل القول في مواقف النحويين من الضرورة

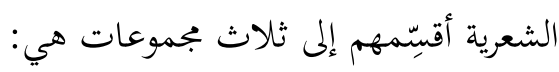

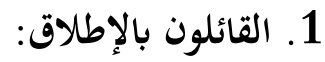

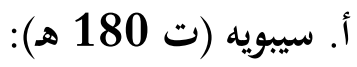

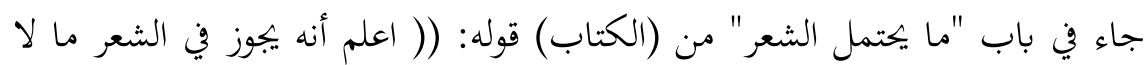

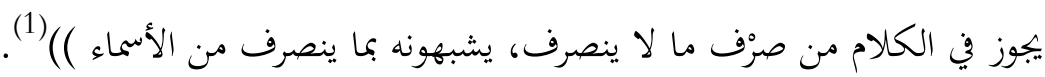

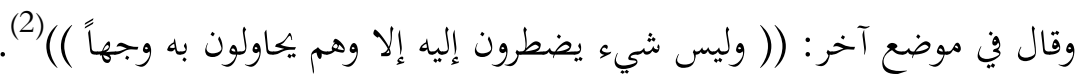

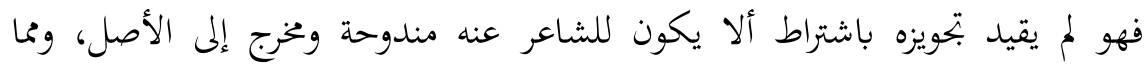

استدل به على صحة ما ذهب إليه قول الشاعر:

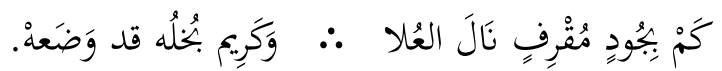

فقد أوضح أن الشاعر اختار في "مقرف" الجرب، وهذا لمان يعني الوقوع في الممنوع، وهو

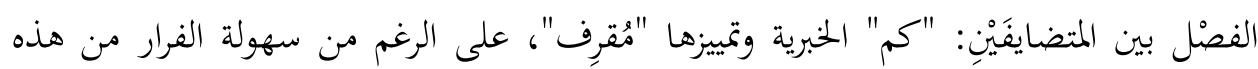

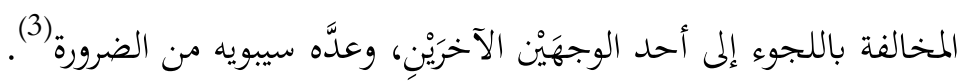

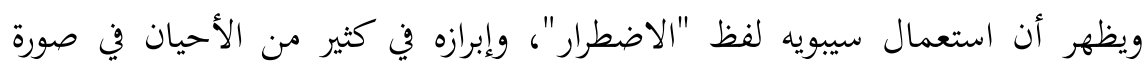

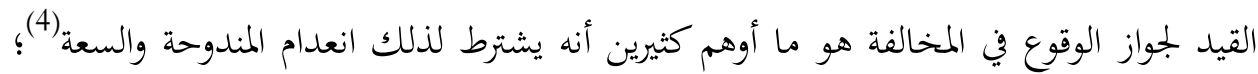
ولكن الصحيح خلافه، وفي كتاب "سيبويه والضرورة الشعرية" عدة أدلة تؤيد ذلك، الكئ منها:

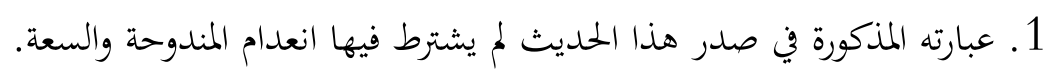

$$
\text { 26 - 26/1 السابق 32/1. }
$$

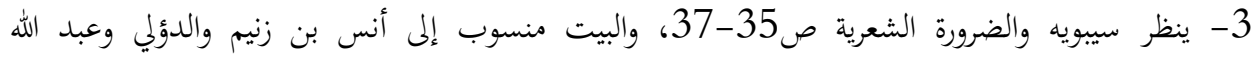

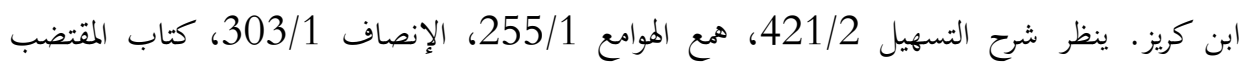

ان $61 / 3$

4ـ منهم أبو حيان (ت 745هـ)، ينظر باب الضرائر في كتابه ارتشاف الضرَب 2377/5. 
2. يمكن إخراج كثير من الشواهد التي ذكرها في حديثه عن أنواع الضرورة من حيز

الضرورة، دون أن يحدث انكسار في وزن البيت أو تغيير في معناه، ومن تلك الأبيات:

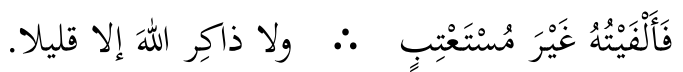

فإن إبقاء التنوين في "ذاكر" يؤدي إلى انكسار وزن البيت؛ لذا اضطر قائله إلى حذف إلى

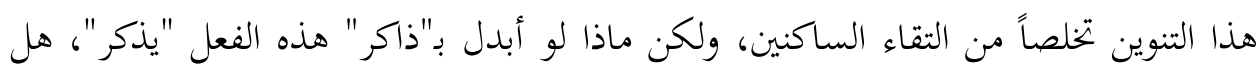

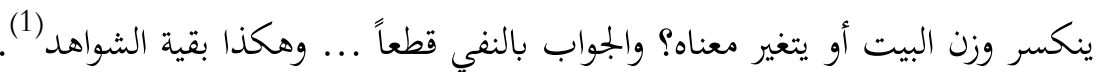

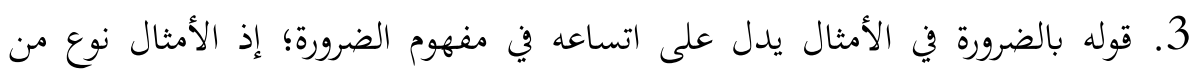

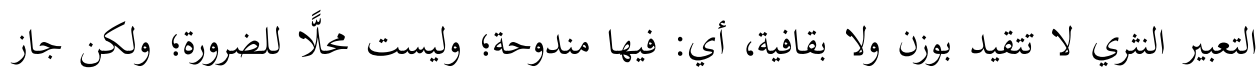
فيها ما جاز في الشعر لكثرة جرياها على الألسنة(2). وذكر إبراهيم حسن إبراهيم: أن سيبويه عطف -أحياناً- لفظ "الاضطرار" على عبارة "ما

يجيوز في الشعر"، وملا كان العطف يقتضي المغايرة، فإن الضرورة عنده نوعان:

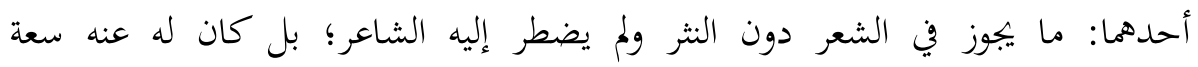

ومندوحة.

والآخر: ما وقع فيه الشاعر بدافع الضيق والاضطرار، ولم يكن له عنه مندوحة. ثم صرَّح بأنه لا يرى هذا الرأي؛ لأن سيبويه استعمل إحدى هاتين العبارتين مع بعض الشواهد، ثم استعمل العبارة الأخرى مع تلك الشواهد نفسها عندما أعاد ذكرها (3). ب. ابن عصفور الإشبيلي (ت 669 هـ): خصص للحديث عن الضرورة الشعرية كتاباً أطلق عليه اسم (ضرائر الشعر)، وفيه تعرف رأيه بوضوح تام لا لبس فيه، فها هو ذا يقول: (( اعلم أن الشعر - كَمَّا كان كلاماً موزوناً يُخرِجه

1- ينظر الكتاب 169/1، والبيت لأبي الأسُود الدؤلي، ينظر همع الهوامع 179/6.

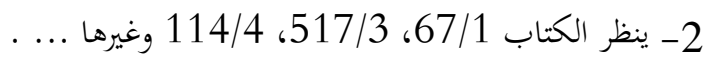

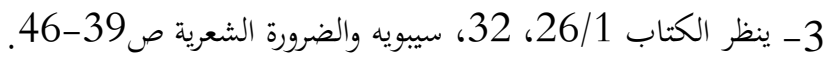


الزيادة فيه والنقص منه عن صحة الوزن، ويُحيله عن طريق الشعر-، أجازت العرب فيه ما لا يجيوز في الكلام، اضطروا إلى ذلك أو لمُ يضطروا إليه؛ لأنه موضع أُلِفَتْ فيه الضرائر. )(). تم استدل على صحة كلامه بقول الشاعر:

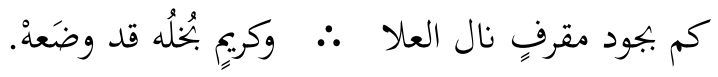
بجرٍِ "مقرف"، وقال -موضحاً-: (( ألا ترى أنه فصل بين "كم" وما أُضيفت إليه بالمجرور؟، والفصل بينهما من قبيل ما يختص بجوازه الشعر، مع أنه لم يضطر إلى ذلك؛ بـ إذ يزول عن الفصل بينهما برفع "مقرف" أو نصْبه ()(1).

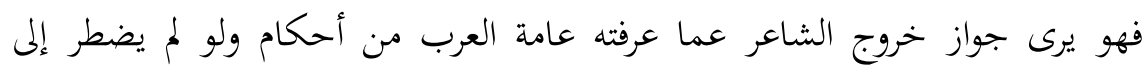
ذلك، بأن كان في استطاعته تفادي الخروج عن تلك الأحكام، وحجته هي أن الشعر ذاته يُبيح له هذا.

\section{ج. البغدادي (ت 1093هـ):}

أكَّد في عدة مواضع من كتابه خزانة الأدب موقفه المؤيّد لرأي الجمهور، ومنها:

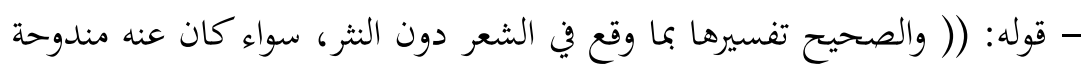

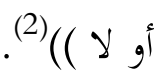

- وقوله: (( والصحيح أفا ما وقع في الشعر، سواء كان عنه مندوحة أم لا ))(3). - وقوله: (( والتحقيق عند المققين أها ما وقع في الشعر، سواء كان للشاعر عنه

$$
\text { مندوحة أم لا (4) (4) (ل) }
$$

- وقوله: (( ومعناها ما وقع في الشعر، سواء كان عنه مندوحة أم لا ))(5). 1- ضرائر الشعر لابن عصفور ص13، وسبق ذكر البيت وتخريهه في هذا البحث ص142.

$$
\begin{array}{r}
.13 / 1-2 \\
.63 / 6-3 \\
.362 / 8-4 \\
.286 / 9-5
\end{array}
$$


- وقوله: (( وهي ما وقع في الشعر وإن كان عنه مندوحة، وهذا هو الصحيح في

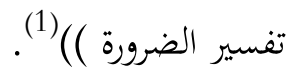

2. - 2. 2 القائلون بالتقييد:

$$
\begin{aligned}
& \text { سأكتفي بالحديث عن أشهرهم وأبرزهم وهو: } \\
& \text { ابن مالك (ت } 672 \text { هـ): }
\end{aligned}
$$

إنه يماثل ابنَ عصفور في وضوح الرأي، ولكنه هنا في تضييق مفهوم الضرورة وتقييده

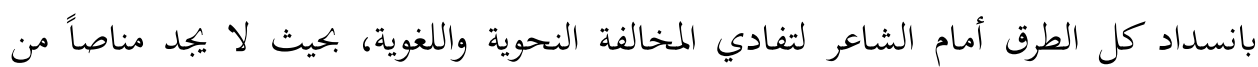
الوقوع فيها، معتمداً في ذلك على اشتقاق الضرورة من الضرر الذي هو النازل الذي لا يُدفع. وقد ذكر الأبيات الآتية لتوضيح رأيه:

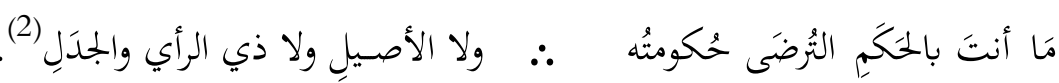

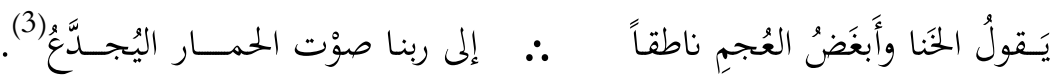

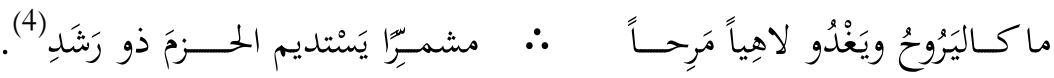
.

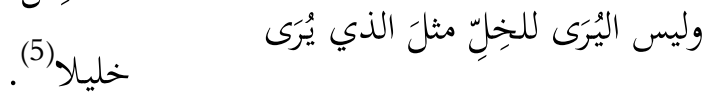

ثم قال: (( وعندي أن مثل هذا غير مخصوص بالضرورة؛ لتمكُّن قائل الأول أن يقول: ما أنت بالحكم المرضى حكومته، ولتمكن قائل الثاني من أن يقول: إلى ربنا صوت الحمار

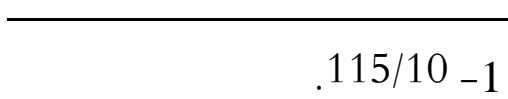

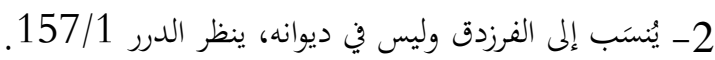

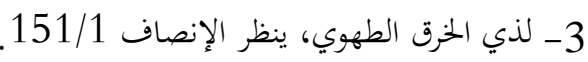
4- المجهول، ينظر همع الموامع 294/1. 5- لمجهول، ينظر شرح التسهيل 201/1. 
يُجُلَّع، ولتمكن الثالث من أن يقول: ما مَن يروح، ولتمكن الرابع من أن يقول: وما مَن يُرَى. فإذ لم يفعلوا ذلك -مع استطاعته- ففي ذلك إشعار بالاختيار وعدم الاضطرار. وأيضاً فمقتضى النظر وصْل الألف واللام -إذ هما من الموصولات الاسمية- بما توصَل به

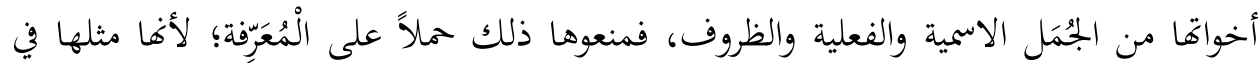

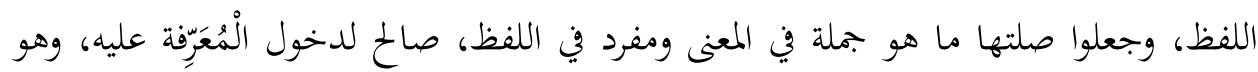
اسم الفاعل وشبهه من الصفات.

ثم كان في التزام ذلك إيهام أن الألف واللام مُعَرِفة لا اسم موصول، فقصدوا التنصيص على مغايرة الْمُعِّفة، فأدخلوها على الفعل المشابه لاسم الفعل وهو المضارع، فلما كان حاملهم

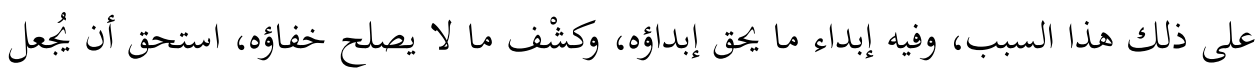
مما يُحكَم فيه بالاختيار، ولا يخص بالاضطرار؛ ولذلك لم يقِلَّ في أشعارهم كما قَلََّ الوصل بجملة

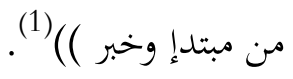

فابن مالك -بناء على قوله-لم يخص هذه الأبيات وما شاهها بما لا مندوحة للشاعر

$$
\text { عنه، أي: بالضرورة، وممن ردوا على ابن مالك فهُمه لمعنى الضرورة: }
$$

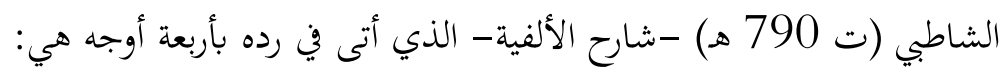

(( أحدها: إجماع النحاة على عدم اعتبار هذا النزع، وعلى إهماله في النظر القياسي لئي

جملة، ولو كان معتبرًا لنبَّهوا عليه.

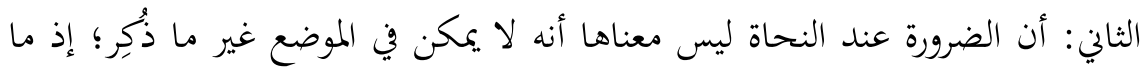
من ضرورة إلا ويمكن أن يُعوَّض من لفظها غيره، ولا يُنكِر هذا إلا جاحد لضرورة العقل، وإنما

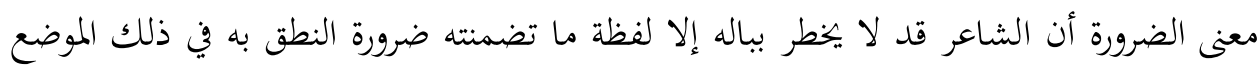
إلى زيادة أو نقص أو غير ذلك، بحيث قد يتنبه غيره إلى أن يحتال في شيء يُزيل تلك الضرورة.

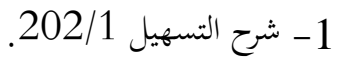


الثالث: أنه قد يكون للمعنى عبارتان أو أكثر، واحدة يلزم ضرورة إلا أها مطابقة

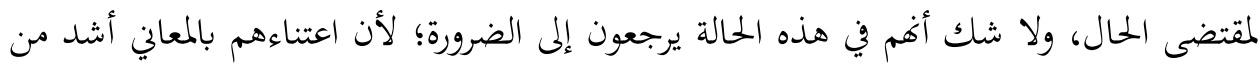

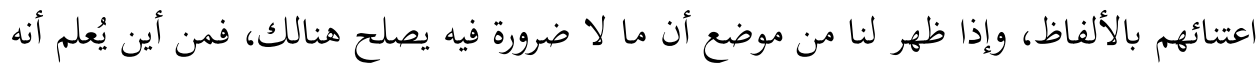
مطابق لمقتضى الحال؟ الرابع: أن العرب قد تأبى الكلام القياسي لعارض زحاف، فتستطيب المزاحف دون غيره

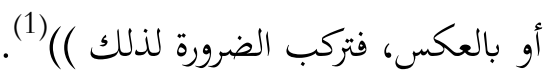
وردَّ عليه -أيضاً - أبو حيان (ت 745 74ه) بأنه لم يفهم معنى قول النحويين، وخلص إلى إلى القول: (( فعلى زعمه لا توجد ضرورة أصلاً؛ لأنه ما من ضرورة إلا ويمكن إزالتها ونظم تركيب آخر غير ذلك الترتيب، وإنما يعنون بالضرورة أن ذلك من تراكيبهم الواقعة في الشعر المختصة به، ولا يقع في كلامهم النثر، وإنما يستعملون ذلك في الشعر خاصة دون الكلام، ولا يعني النحويون

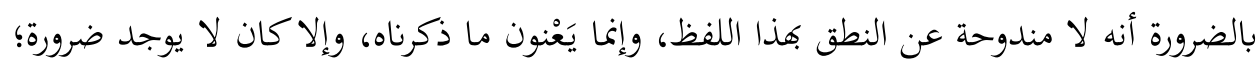

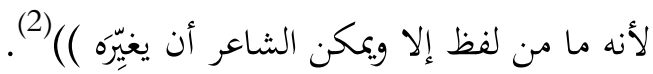
وقال الألوسي (ت 1342 هـ) نفسه -بعد ذلك-: (( والعبد الفقير قد جرى في هذا الكتاب على ما جرى عليه الجمههور، فإنه الأنسب بمذاق العرب والتوسع عليهم بفن القريض، فإغم محتاجون إليه في الغناء بمكارم أخلاقهم وطيب أعراقهم، وذكر أيامهم الصالحة وأوطاهم

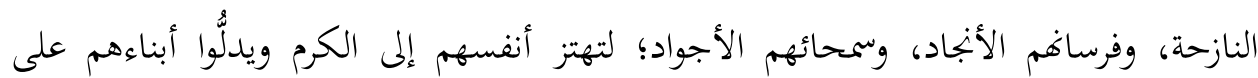
حسن الشيم، مع كونه ديوان مآثرهم، وسجل مفاخرهم؛ فلذلك اختص الشعر بخصائص تمييزاً له من بين أنواع الكلام، وتسهيلاً لسلوك جادة النظام )(3). وقال باحث معاصر:

$$
\begin{aligned}
& \text { 1- خزانة الأدب 33/1-34. } \\
& \text { 2- الضرائر، الألوسي صن } \\
& \text { 3- السابق ص9. }
\end{aligned}
$$


( ( مما لا شك فيه أن مذهب ابن مالك ظاهر الفساد؛ لاعتماده على مجرد التفسير

اللغوي البحت لمعنى الضرورة، دون مراعاة لطبيعة الشعر، ودون النظر إلى أن الشعر لغة العواطف والوجدان، ورُبَّ كلمة يراها الشاعر مفعمة بالمعاني التي بتحيش في صدره، صادقة في التعبير عنها، مع ما في استعمالها من مخالفة لسنن الكلام وقواعد النحاة، ولا يرى ذلك في مرادفاها مما يساير سنن الكلام وقواعد النحاة )(1( ). 3. المترددون بين الإطلاق والتقييد:

\section{أبو سعيد السيرافي (ت 368 هـ):}

هو من أشهرهم، وضع فيها كتاباً سماه ضرورة الشعر ضمنه رأيه فيها وذكر أنواعها، ومن مطالعة هذا الكتاب يتبيَّن أنه مضطرب في وضع صيغة ثابتة لمفهومها، فيذكر أن الضرورة هي ما يُستجاز في الشعر ولا يُستجاز في غيره من الكلام، فهو يقول: (( اعلم أن الشعر لَمَّا

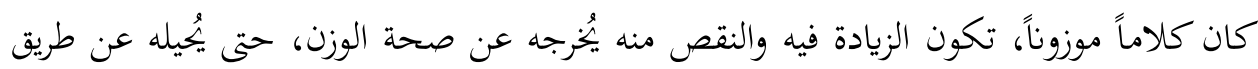

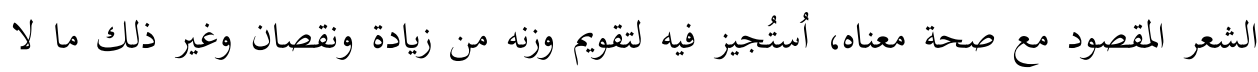

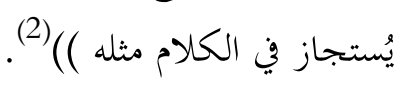

ولكن ما يُستجاز له حدود، على الشاعر ألا يتجاوزها، وإلا لم يعد الشعر شعراً ولا الضرورة ضرورةً؛ لذا سارع السيرافي إلى رسم تلك الحدود بقوله: (( وليس في شيء من ذلك رفْع منصوب، ولا نصْب مخفوض، ولا لفظ يكون المتكلم فيه لاحناً، ومتى وُّجد هذا في شعر كان

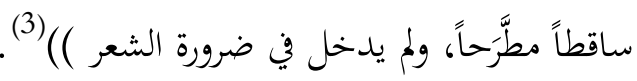

1- 1 سيبويه والضرورة الشعرية، ص23، 33.

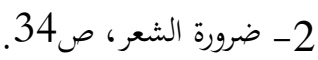

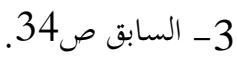


وهذا يعني أن السيرافِ يضِِّق مفهوم الضرورة ولا يتوسَّع فيه، ولكنه لا يلبث حتى يغِِِّر موقفه رأساً على عقب، وذلك بإدخاله في الضرورة كل ما خالف الإعراب والمعنى. فقد عرض شاهدين مختلفين، أشار في كلامه على أحدهما إلى وضوح المعنى بقوله: (( اعلم أن الشاعر قد يضطر حتى يضع الكلام في غير موضعه الذي ينبغي أن يوضع فيه، فيزيله عن قصده الذي لا يحسن في الكلام غيره ويعكس الإعراب، فيجعل الفاعل مفعولاً، والمفعول فاعلاً، وأكثر ذلك فيما لا يشكل معناه، فمن ذلك قول الأخطل:

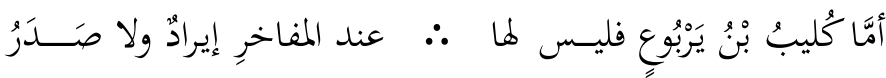

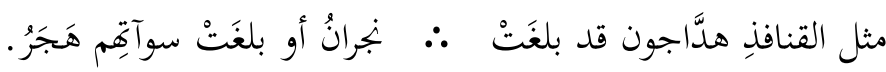

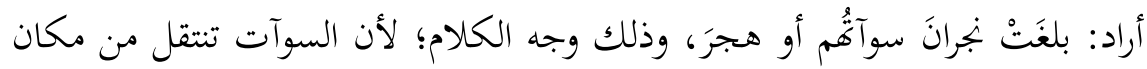

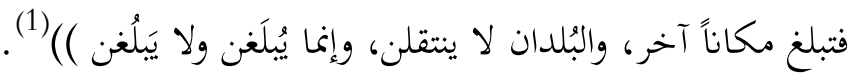
أي أن السبب في هذا الحروج على الحكم النحوي هو أن الشاعر مقيَّد بقافية رائََّّة مضمومة، فلا بد أن تكون قافية البيت الثاني راء مضمومة -أيضاً-، ولعل ما جرَّأه على هذه المخالفة وزيَّها له هو وضوح المعنى. وأما الشاهد الآخر وهو قول الشاعر:

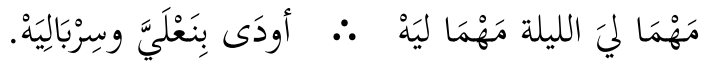

فقد صرَّح السيرافي (ت 368 هـ) بأن التغيير الذي أحدثه الشاعر لم تتوقف عليه صحة معنى البيت ولا سلامة وزنه، غير أنه التمس له العذر في استقباحه تكرير لفظين فقال: (( و"مهما" لا تكون إلا في الشرط والجزاء، كقولك: مهما تفعلْ أفعلن، وهذا الشاعر لمُ يرد

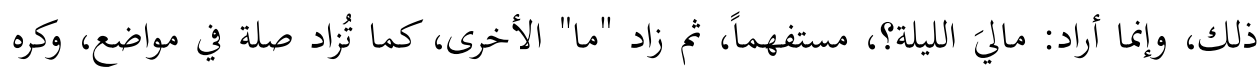
1- ضرورة الشعر ص173، 174، وينظر شرح ديوان الأخطل ص178. 
اجتماع اللفظين فقلب من الألف الأولى هاءً، ولو لم يقلب لم ينكسر البيت ولم يفسد، ولكنه استقبح تكرير اللفظين، ففعل فيه ما يفعله في غير الضرورة، لتَشارَّكهما في القبح عنده )(1).

1- ضرورة الشعر ص170، والبيت لجاهلي اسمه عمرو بن ملقط الطائي، ينظر خزانة الأدب 18/9. 


\section{المطلب الرابع: رأيي في المصطلَح.}

مما سبق تبيَّن أن للنحاة رأيَيْنِ متباينَيْنِ في المعنى الاصطلاحي للضرورة، يقوم أحدهما

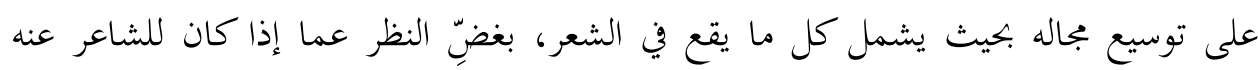

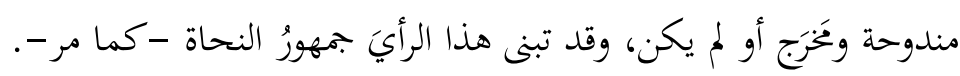

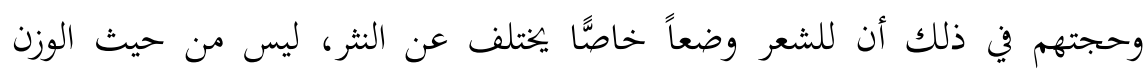
والقافية فحسب؛ بل -أيضاً- من حيث ما في الشعر من مشاعر وأحاسيس وصور وأخيلة،

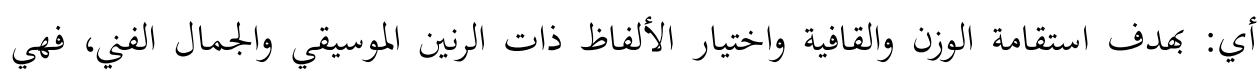
بذلك (( أثر إيجابي للعلاقة الحية بين العمل الأدبي والتراث، وفيها يظهر التعامل الذكي والتناول

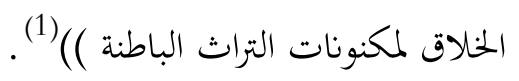
وهذا ابن الأثير (ت 637 هـ) يقول على لسان البيانيين -وهو منهم-: (( ونحن في

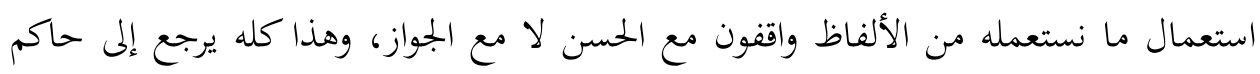

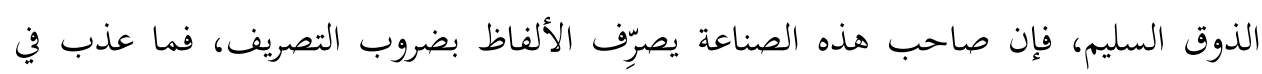
فمه منها استعمله، وما لفظه فمُه ترَكه ()(2). وقد اختصر بعض الباحثين المسألة بالقول: (( للشعر لغته ومنطقه، ولا يحق أن نحكِم

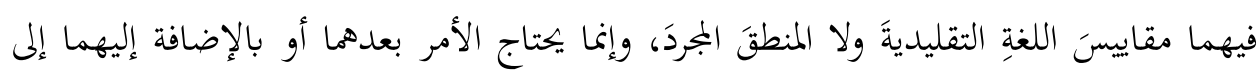

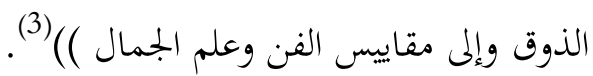
أي أفم غلَّبوا الشاعرية على اللغة، فنظروا إلى ما يطلبه الشعر من وزن وقالى وقافية وألفاظ

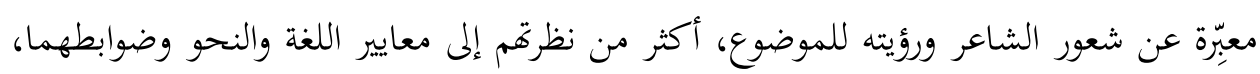
فحكموا بأن كل ما وقع فيه الشاعر من مخالفات للأحكام إنما هو من قبيل الضرورة، فجوَّزوه له ورخَّصوا له فيه.

$$
\begin{aligned}
& \text { 1- الضرورة الشعرية، من المقدمة. } \\
& \text { 2- 287/1 المثل السائر 287. } \\
& \text { 3- ضرائر الشعر للقيرواني، من تقديم المحقعَيْنِ. }
\end{aligned}
$$


وأما الرأي الآخر فيضيّق مجال الضرورة جدًّا، بحيث لا يقع الشاعر فيها إلا إذا عدِم كل

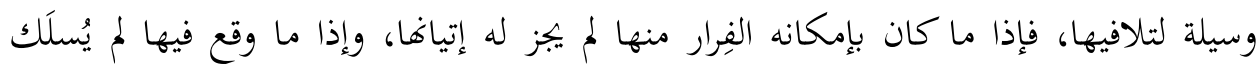

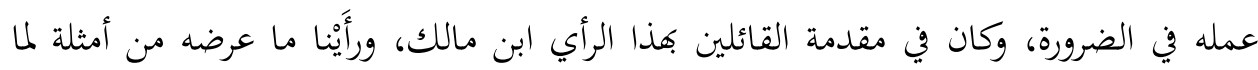
قيل إنه ضرورة، وما هو عنده بضرورة؛ لإمكانية اختيار الشاعر ألفاظاً أخرى لا توقعه فيها.

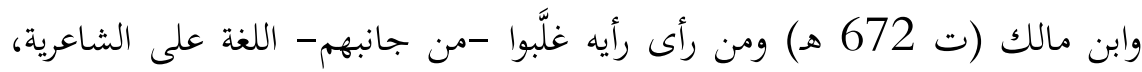

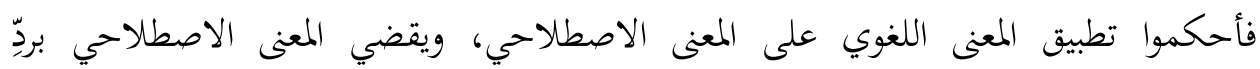

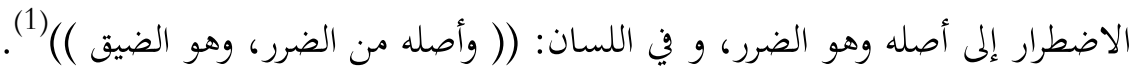

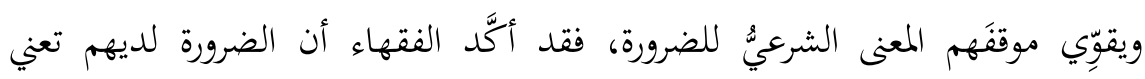

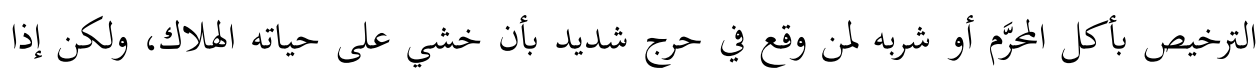

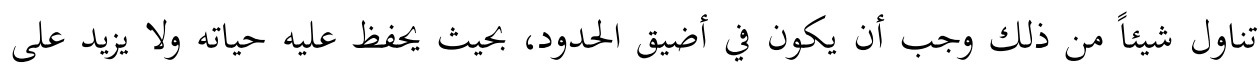

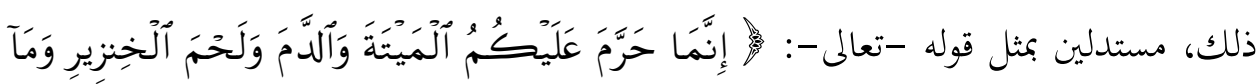

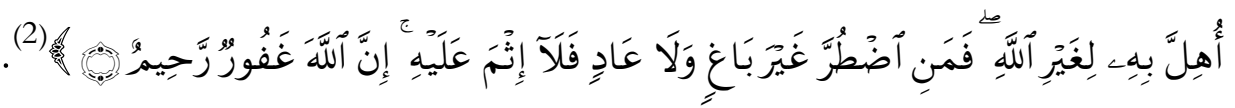
جاء في تفسير الآية الكريمة: (( والمضطر هو الذي ألجأته الضرورة، أي: الحاجة، أي: اضطر إلى أكل شيء من هذه المحَّمَات ... فعُعِلم أن نفي الإثم عن المضطر فيما يتناوله من هذه

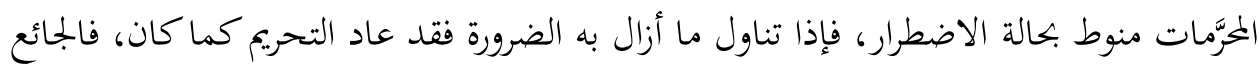

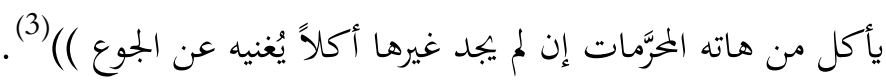

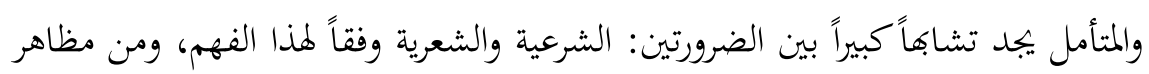
هذا التشابه ما ذكره الألوسي (ت 1342هـ) من مسائل في الضرورة الشعرية (( يتوقف عليها

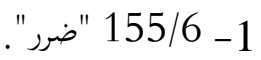

2- 2- - سورة البقرة: 173. 3- تفسير التحرير والتنوير 120/2، 121 - تسرة 121. 
معرفة هذا الفن ))، وهي خمس عشرة مسألة موافقة في أكثرها لما ذكره الفقهاء والمفسرون عن الضرورة الشرعية كما مر -قبل قليل- (1).

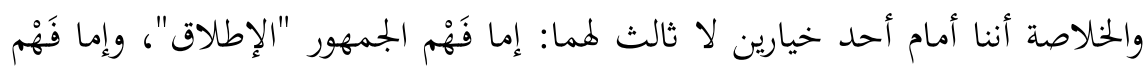

$$
\text { الأقلية "التقييد". }
$$

فإذا ما اخترنا قول الأقلية كان المصطلح منطبقاً تماماً على مدلوله؛ لأنه موافق لمعناه

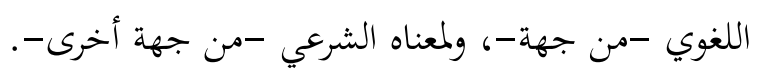

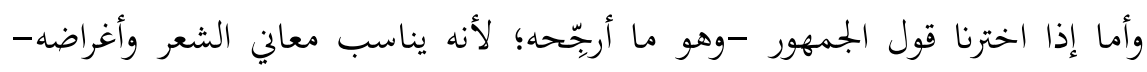

فعلينا أن نتخلَّى عن هذا المصطلح هذا اللفظ؛ لأن اللفظ والمعنى متضادان - كما رأينا بوضوح

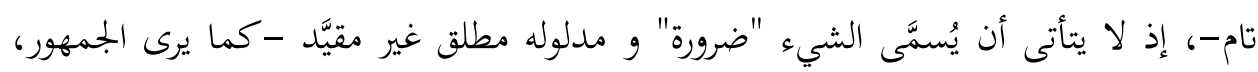

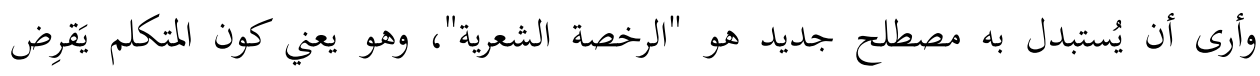

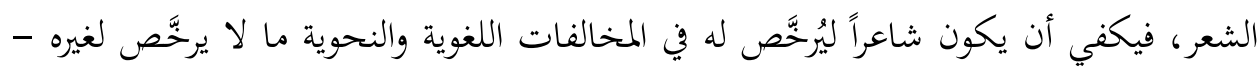

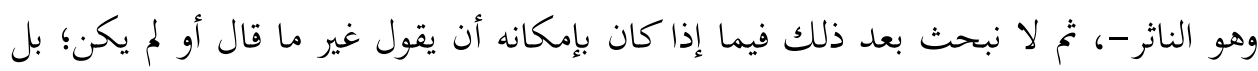
لا نفكر في هذا الأمر أصلاً.

وبذلك أرجو أن أكون قد احترمتُ رأي كلٍّ من الطرفين، بأن أكَّدت صحة فَهْمر

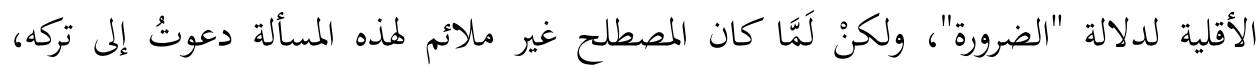

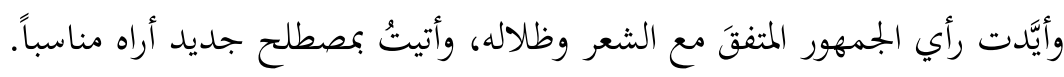

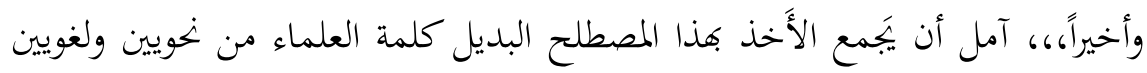
وبيانيين وشعراء وأدباء في هذه المسألة، و أن يُُرِجها من قائمة المسائل الخلافية.

1 - ينظر مقدمة كتابه الضرائر وما يسوغ للشاعر دون الناثر. 


\section{المصادر والمراجع}

القرآن الكريم، مصحف المدينة.

1- الأصول في النحو، لابن السراج، تحقيق: د. عبد الحسين الفتلي، مؤسسة الرسالة، بيروت،

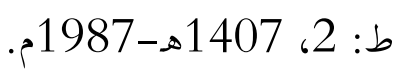

2- الإنصاف في مسائل الخلاف، للأنباري، ومعه كتاب الانتصاف من الإنصاف، لمحمد محيي الدين عبد الحميد، دار الفكر، (د. ط، ت).

3- تاج العروس من جواهر القاموس، للزبيدي، المطبعة الخيرية، القاهرة، ط: 1، 1306هـ. 4- التعريفات، للجرجاني، مكتبة لبنان، بيروت، 1969م، (د. ط).

5- تفسير التحرير والتنوير، محمد الطاهر بن عاشور، الدار التونسية للنشر، 1984م. .( . (.)

6- تَذيب اللغة، للأزهري، حققه تُحََّّ أبو الفضل إبراهيم، راجعه: علي عُمَّم البجاوي، الدار المصرية للتأليف والترجمة، (د. ط، ت). 7- خزانة الأدب ولب لباب لسان العرب، لعبد القادر البغدادي، تحقيق: عبد السلام هارون، مكتبة الخانجي، القاهرة، ط: 3، 1939م. 8- الخصائص، لابن جني، تحقيق: الشربيني شريدة، دار الحديث، القاهرة، 1428هـ. 2007 (د. 2007

9- الدرر اللوامع على شواهد شرح هع الهوامع، للشنقيطي، مطبعة كردستان. (د. ط، ت). 10- ديوان الفرزدق، دار بيروت للطباعة والنشر، 1980م، (د. ط).

11- سنن ابن ماجة، صححه مُحَّم فؤاد عبد الباقي، دار إحياء الكتب العربية، القاهرة، (د. ( ) 
12- سيبويه والضرورة الشعرية، لإبراهيم حسن، مطبعة حسان، القاهرة، ط: 1، 1983م. 13- شرح التسهيل، لابن مالك، تحقيق: عبد الرحمن السيد و مُحَّمَ بدوي المختون، دار هجر للطباعة، ط: 1، 1990، 1900. 14- شرح ديوان الأخطل، صنَّفه وكتب مقدماته وشرح معانيه وأعدَّ فهارسه إيليَّا سليم الحاوي، دار الثقافة، بيروت، ط: 2، 1979م. 1979. 15- الصحاح (تاج اللغة وصحاح العربية)، للجوهري، تحقيق: أحمد عبد الغفور عطار، دار العلم للملايين، بيروت، ط: 2، 1979م. 16- ضرائر الشعر، لابن عصفور، تحقيق: السيد إبراهيم تُحَّه، دار الأندلس للطباعة والنشر والتوزيع، بيروت، (د. ط، ت). 17- ضرائر الشعر، أو كتاب ما يجوز للشاعر في الضرورة، للقيرواني، تحقيق: د. مُحَّم زغلول سلام و د. مُحَّم مصطفى هدارة، نشر: منشأة المعارف بالإسكندرية، (د. ط، ت). 18- الضرائر وما يسوغ للشاعر دون الناثر، للألوسي، مكتبة دار البيان، بغداد، دار صعب،

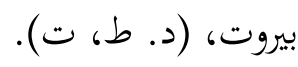
19- الضرورة الشعرية "دراسة أسلوبية"، السيد إبراهيم وُمَّة، دار الأندلس للطباعة والنشر والتوزيع، ط: 2، 1401هـ-1981م. 20- ضرورة الشعر، لأبي سعيد السيرافي، تحقيق: د. رمضان عبد التواب، دار النهضة العربية، بيروت، 1985م، (د. ط). 21- فتح القدير الجامع بين فني الرواية والدراية من علم التفسير، لمحمد بن علي الشوكاني، دار الفكر للطباعة والنشر والتوزيع، بيروت، 1403هـ-1983م، (د. ط). 
22- الفهرست، لابن النديم، ضبطه وشرحه: د. يوسف علي طويل، دار الكتب العلمية،

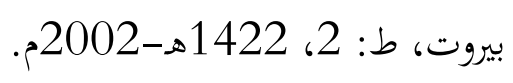

23- الكافي (معجم عربي حديث)، لخمد الباشا، شركة المطبوعات للتوزيع والنشر، بيروت،

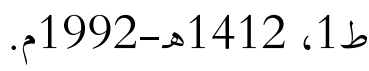
24- الكتاب، لسيبويه، تحقيق وشرح: عبد السلام مُحمَّه هارون، مكتبة الخنانجي، القاهرة، ط:

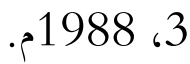

25- كتاب جمهرة اللغة، لابن دريد، حققه وقدَّم له: د. رمزي منير بعلبكي، دار العلم للملايين، بيروت، ط: 1، 1987، 1987م. 26- كتاب المقتضب، للمبرد، تحقيق: ثُحَّمَ عبد الخالق عضيمة، لجنة إحياء التراث الإسلامي،

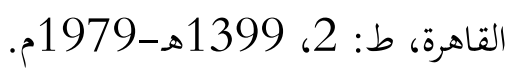
27- كشف الظنون عن أسامي الكتب والفنون، لحاجي خليفة، دار الكتب العلمية، بيروت،

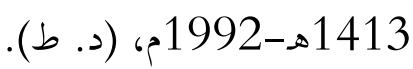

28- لسان العرب، لابن منظور، طبعة مصورة عن طبعة بولاق، الدار المصرية للتأليف

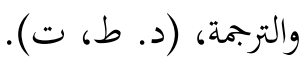
29- المثل السائر في أدب الكاتب والشاعر، لابن الأثير، تحقيق: تُحَّمَ محيي الدين عبد الحميد، مكتبة البابي الحلبي، 1358هـ-1939م، (د. ط). 30- محيط الخيط، قاموس مطوَّل للغة العربية، للبستاني، مكتبة لبنان، بيروت، 1977مدان، 1977م، $(b . د)$ 
31- المزهر في علوم اللغة وأنواعها، للسيوطي، شَرَه وضَبطه وصحَّحه وعنْون موضوعاته وعلَّق

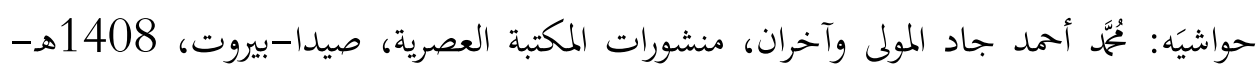

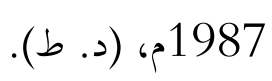

32- معجم المؤلفين، لعمر رضا كحالة، مؤسسة الرسالة، ط: 1، 1414 1414هـ-1993م.

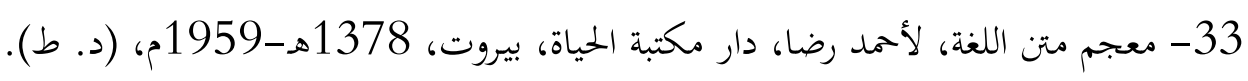

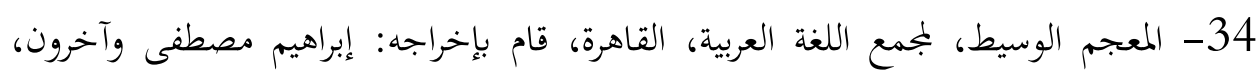

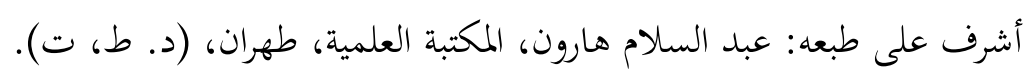
35- الممتع في التصريف، لابن عصفور، تحقيق: د. فخر الدين قباوة، منشورات دار الآفاق

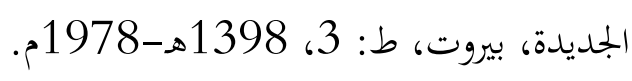
36- المادي إلى لغة العرب، قاموس عربي-عربي، لحسن سعيد الكرمي، دار لبنان للطباعة

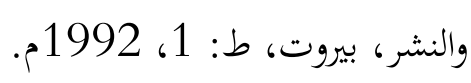
37- همع الهوامع في شرح جمع الجوامع، للسيوطي، تحقيق: د. عبد العال سالم مكرم، دار البحوث العلمية، الكويت، 1400هـ-1980م، (د. ط). 